\title{
AOR
}

Selected Papers of \#AolR2020: The $21^{\text {st }}$ Annual Conference of the Association of Internet Researchers Virtual Event / 27-31 October 2020

\section{DIGITAL STRESS IN EVERYDAY LIFE}

Jeffrey Wimmer

University Augsburg - Department for Media, Knowledge and Communication

Lisa Waldenburger

University Augsburg - Department for Media, Knowledge and Communication

Research question: What is digital stress? How do the subjects perceive it and how do they describe it?

It is now common sense that digitalization changes the living conditions and routines of every individual dramatically. If everyday discourses are primarily concerned with new possibilities or negative implications associated with the use of digital technologies and media, we would like to turn to a more holistic perspective which builds on subjective perceptions as well as practices. This ensures not only that the ambivalent potential of digital media is taken into account, but also that the media repertoire of the users is considered in its full complexity.

Existing research on this field of investigation resides under the term "digital stress" (Weinstein and Selman 2016; Weinstein et al. 2016; Reineke et al. 2016; Hefner and Vorderer 2017). In this sense, stress is the "result of an imbalance between external demands and the available possibilities to cope with them" (Lohmann-Haislah 2012). Stress caused by digital technologies and media is referred to here as "digital stress". This term ties in with the concept of "technostress" introduced by clinical psychologist Brod (1982). This describes the perceived inability of an individual to deal with new technology in a healthy way. Digital stress, analogous to technostress, therefore includes tension, fatigue, excessive demands and the concern that an individual is not able to handle modern digital technologies adequately (Salanova et al. 2013).

This phenomenon has been a highly regarded topic in the scientific literature (especially in business informatics) over the last decade (e.g. Ragu-Nathan et al. 2008; Ayyagari et al. 2011; Tarafdar et al. 2011; Riedl 2013; Adam et al. 2014; Gimpel et al. 2015; Maier et al. 2015b; Lee et al. 2016; Adam et al. 2017). Research in this area generally refers back to the transactional stress model of Lazarus and Folkman (1984). Stress is either measured by established scales or medically in medicine by the increase in cortisol levels.

Suggested Citation (APA): Wimmer, J., Waldenburger, L. (2020, October). Digital Stress In Everyday Life. Paper presented at AoIR 2020: The $21^{\text {th }}$ Annual Conference of the Association of Internet Researchers.

Virtual Event: AolR. Retrieved from http://spir.aoir.org. 
The experience of digital stress, as far as we want to follow the theoretical approaches of Lazarus, depends on subjective dispositions as well as on the situation itself and therefore cannot be generalized. For example, 30 new e-mails in a waiting room can be a welcome occupation; shortly before the end of work, however, it is a stress-inducing factor. The subjective habits of the individual also play a role. But in the most studies digital stress as a theoretical phenomenon is always approached deductively, so if the situational and subjective conditions for digital stress are fulfilled, then the subject is digitally stressed. The conditions applied are derived from explorative studies and causal considerations. However, the word combination "digital stress" seems to be a media-influenced, rather scientifically located concept, which, we assume, has no verbal equivalent in everyday interaction. The distinction between digital and analogue stress seems to have no relevance for the interactors in everyday situations. Furthermore, studies show that people hardly make any reference to "stress" or "being stressed" when describing their use of digital technologies (Röser et al. 2017).

For this reason, in our research project we want to explore inductively the perceived characteristics and forms of digital stress in people's everyday life. How do they describe digital stress, is it different from other forms of stress and how does digital stress express itself? The focus is not genuinely on the topic of digital stress, but on the attempt to make this phenomenon empirically tangible and to link it to concepts of digital wellbeing. To this end, we are conducting explorative, open guideline interviews in spring 2020 , methodologically oriented on grounded theory. The aim is to make digital stress qualitatively measurable by identifying the categories with which subjects act in the context of digital stress. At AolR we will present data that provides information about the subjective perception of digital stress by users, everyday situations and contexts in which they experience it, and possibly copying strategies that different groups of media users have developed so far in this context.

This survey is the starting point of a 4-year research project on digital stress in everyday media life, which includes qualitative interviews, a 2-year panel study and ethnographic observations.

\section{References}

Adam, M. T. P., Gimpel, H., Maedche, A. und Riedl, R. (2014). Stress-Sensitive Adaptive Enterprise Systems: Theoretical Foundations and Design Blueprint. Proceedings of the Neuro IS Retreat 2014.

Ayyagari, R., Grover, V. und Purvis, R. (2011). Technostress: Technological Antecedents and Implications. MIS Quarterly, 35(4), 831-858.

Gimpel, H., Regal, C. und Schmidt, M. (2015). myStress: Unobtrusive SmartphoneBased Stress Detection. ECIS 2015 Research-in-Progress Papers. Paper 16.

Hefner, D. und Vorderer, P. (2017). Digital Stress. Permanent Connectedness and Multitasking. In L. Reinecke und M. B. Oliver (Hrsg.), The Routledge Handbook of 
Media Use and Well-Being: International Perspective on Theory and Research on Positive Media Effects (S. 237-249). New York, NY: Routledge.

Lazarus, R. S. (1999). Stress and emotion: A new synthesis. New York, NY: Springer Publishing Company.

Lazarus, R. S. und Folkman, S. (1984). Stress, appraisal, and coping. New York, NY: Springer Publishing Company.

Lee, A. R., Son, S. und Kim, K. K. (2016). Information and communication technology overload and social networking service fatigue: A stress perspective. Computers in Human Behavior, 55, 51-61.

Lohmann-Haislah, A. (2012). Stressreport Deutschland 2012 - Psychische Anforderungen, Ressourcen und Befinden. Dortmund/ Berlin/ Dresden: Bundesanstalt für Arbeitsschutz und Arbeitsmedizin.

Maier, C., Laumer, S., Weinert, C. und Weitzel, T. (2015). The effects of technostress and switching stress on discontinued use of social networking services: a study of Facebook use. Information Systems Journal, 25(3), 275-308.

Ragu-Nathan, T. S., Tarafdar, M., Ragu-Nathan, B. S. und Qiang, T. (2008). The Consequences of Technostress for End Users in Organizations: Conceptual

Development and Empirical Validation. Information Systems Research, 19(4), 417-433.

Reinecke, L., Aufenanger, S., Beutel, M., Dreier, M., Quiring, O., Stark, B., Wölfling, K. und Müller, K. (2016). Digital Stress over the Life Span: The Effects of Communication Load and Internet Multitasking on Perceived Stress and Psychological Health Impairments in a German Probability Sample. Me-dia Psychology, 20(1), 90-115.

Riedl, R. (2013). On the Biology of Technostress: Literature Review and Research Agenda. ACM SIGMIS Database, 44(1), 18-55.

Röser, J. (2017). Silversurfer 70plus. Qualitative Fallstudien zur Aneignung des Internets in der Renten-phase. München: Kopaed.

Salanova, M., Llorens, S. und Cifre, E. (2013). The Dark Side of Technologies: Technostress among users of information and communication technologies. International Journal of Psychology, 48(3), 422-436.

Tarafdar, M., Tu, Q., Ragu-Nathan, T. S. und Ragu-Nathan, B. S. (2011). Crossing to the dark side: Examining creators, outcomes, and inhibitors of technostress. Communications of the ACM, 54(9), 113-120.

Weinstein, E. C. und Selman, R. L. (2016). Digital stress: Adolescents' personal accounts. New Media \& Society, 18(3), 391-409. 
Weinstein, E. C., Selman, R. L., Thomas, S., Kim, J. E., White, A. E. und Dinakar, K. (2016). How to cope with digital stress: The recommendations adolescents offer their peers online. Journal of Adolescent Research, 31(4), 415-441. 